\title{
Regulation of glucose uptake
} in lymphoma cell lines by c-MYCand PI3K-dependent signaling pathways and impact of glycolytic pathways on cell viability

Martina Broecker-Preuss ${ }^{1,3^{*}} \mathbb{0}$, Nina Becher-Boveleth ${ }^{1,2,4}$, Andreas Bockisch¹, Ulrich Dührsen² and Stefan Müller ${ }^{1}$

\begin{abstract}
Background: Changes in glucose and energy metabolism contribute to the altered phenotype of cancer cells and are the basis for positron emission tomography with ${ }^{18} \mathrm{~F}$-fluoro-2-deoxy-D-glucose (FDG) to visualize tumors in vivo. The molecular background of the enhanced glucose uptake and its regulation in lymphoma cells is not fully clarified and may provide new possibilities to reverse the altered metabolism. Thus in this study we investigated regulation of glucose uptake by different signaling pathways. Furthermore, the effect of the glucose analog 2-deoxy-D-glucose (2-DG) alone and in combination with other inhibitors on cell survival was studied.
\end{abstract}

Methods: An FDG uptake assay was established and uptake of FDG by lymphoma cells was determined after incubation with inhibitors of the c-MYC and the PI3K signalling pathways that are known to be activated in lymphoma cells and able to regulate glucose metabolism. Inhibitors of MAPK signalling pathways whose role in altered metabolism is still unclear were also investigated. Expression of mRNAs of the glucose transporter 1 (GLUT1), hexokinase 2 (HK2), glucose-6-phosphatase (G6Pase) and lactate dehydrogenase A (LDHA) and of the glucose metabolism-regulating micro RNAs (miRNA) miR21, -23a, -133a, -133b, -138-1 and -143 was determined by RT-PCR. Cell viability was analysed by MTT assay.

Results: Treatment with the c-MYC inhibitor 10058-F4 and inhibitors of the PI3K/mTOR pathway diminished uptake of FDG in all three cell lines, while inhibition of MAPK pathways had no effect on glucose uptake. Expression of glycolysis-related genes and miRNAs were diminished, although to a variable degree in the three cell lines. The c-MYC inhibitor, the PI3K inhibitor LY294002, the mTOR inhibitor Rapamycin and 2-DG all diminished the number of viable cells. Interestingly, in combination with 2-DG, the c-MYC inhibitor, LY294002 and the p38 MAPK inhibitor SB203580 had synergistic effects on cell viability in all three cell lines.

Conclusions: C-MYC-and PI3K/mTOR-inhibitors decreased viability of the lymphoma cells and led to decreased glucose uptake, expression of glycolysis-associated genes, and glucose metabolism-regulating miRNAs. Inhibition of HK by 2-DG reduced cell numbers as a single agent and synergistically with inhibitors of other intracellular pathways. Thus, targeted inhibition of the pathways investigated here could be a strategy to suppress the glycolytic phenotype of lymphoma cells and reduce proliferation.

Keywords: Warburg effect, Glucose metabolism, Lymphoma, ${ }^{18}$ F-fluoro-2-deoxy-D-glucose, 2-deoxy-D-glucose

\footnotetext{
*Correspondence: martina.broecker@uni-due.de

1 Department of Nuclear Medicine, University Hospital Essen, Hufelandstr.

55, 45122 Essen, Germany

Full list of author information is available at the end of the article
} 


\section{Background}

Altered metabolism is a characteristic of most cancer cells and contributes to the needs of transformed cells for rapid proliferation, enhanced energy turnover, anabolic pathways and regulation of redox potential [1, $2]$. Both normal and tumor cells use glucose and glutamine as substrates for ATP synthesis and production of components of cellular metabolism like amino acids, nucleosides and fatty acids [3]. Non-transformed cells predominantly use glycolysis and the TCA cycle to metabolize glucose to $\mathrm{CO}_{2}$ and $\mathrm{H}_{2} \mathrm{O}$. Cancer cells on the other hand take up larger amounts of glucose compared normal cells and metabolize it through glycolysis at higher rates [3]. The pyruvate produced by glycolysis in cancer cells is preferentially metabolized to lactate by cytoplasmic lactate dehydrogenases [4]. This shift from ATP production through oxidative phosphorylation to ATP generation through glycolysis is called "aerobic glycolysis" or the "Warburg effect". It occurs even in the presence of sufficient oxygen and was first described by Otto Warburg [5].

Based on the prevalence of the enhanced glucose uptake and metabolism in cancer cells, positron emission tomography (PET) with the glucose analogue ${ }^{18} \mathrm{~F}$-fluoro2-deoxy-D-glucose (FDG) is a non-invasive molecular imaging tool to detect many tumor entities and monitor therapeutic response by analysing tumor metabolic activity $[4,6]$. FDG, similar to glucose, is transported into the cell via glucose transporters (GLUTs) and is phosphorylated by hexokinase (HK) to FDG-6-phosphate. FDG6-phosphate is trapped in the cell since it is no substrate for glycolytic or pentose phosphate pathways, unable to diffuse out of the cell and it is dephosphorylated slowly. Thus, FDG accumulates in the cell at a rate proportional to glucose utilization and tumors with an increased uptake of glucose can be visualized non-invasively by PET which also enables quantitative assessment of glucose utilization $[7,8]$.

Metabolic changes in cancer were considered as a secondary effect of the transformation process. Molecular mechanisms that lead to metabolic reprogramming and to the metabolic phenotype of cancer cells are only partly understood and include activation of oncogenes and kinases like c-MYC, members of the phosphoinositide 3-kinase (PI3K) signalling pathway [PI3K, protein kinase B (AKT), mammalian target of rapamycin (mTOR)], stabilization of transcription factors like hypoxia-inducible factor 1 (HIF-1) and inactivation of tumor suppressor genes like p53 $[3,4,9]$. Concordant with the increased uptake of glucose, expressions of GLUT genes, namely GLUT1 and genes of glycolytic enzymes are increased in many cancers [Review: 10]. Besides transcription factors, gene expression is regulated also by microRNAs
(miRNAs) which are endogenous small non-coding RNAs of 18-25 nucleotides and regulate gene expression by binding to the $3^{\prime}$-untranslated region of the target mRNA [11]. Depending on their target genes, miRNA can function as tumor-suppressors or oncogenic miRNAs. A few specific miRNAs are described to be involved in glucose metabolism in cancer cells including miR21, -23a,- 133a, -133b, -138-1 and -143 [12-14].

Non-Hodgkin's lymphoma (NHL) is a heterogeneous group of diseases and includes several lymphoma subtypes like diffuse large B-cell lymphoma (DLBCL), Burkitt lymphoma, mantle cell lymphoma, follicular lymphoma and others [15]. NHLs display enhanced FDG uptake and thus PET is used for staging, monitoring of therapy response and prognostication of these patients. High glucose uptake is seen as a surrogate marker of an aggressive tumor and associated with poor outcome in DLBCL $[16,17]$. Patients with NHL are usually treated with a chemotherapeutic regime including rituximab, cyclophosphamide, doxorubicin, vincristine and prednisone (R-CHOP). However, only in $40-50 \%$ of patients a complete response is achieved after first therapy [18]. Interim PET after a few cycles of chemotherapy may be used according to current guidelines for NHL patients to predict response but currently without a recommendation to change therapy in non-responders $[19,20]$. Clinical trials concerning the value of a change of the therapeutic regime in non-responding patients based on interim PET, e.g. the PETAL trial (PET-guided therapy of aggressive non-Hodgkin lymphoma) [21, 22] are performed.

The involvement of PI3K, c-MYC and MAPK pathways on glucose uptake, expression of glycolysis-associated genes and cell proliferation in lymphoma is not known yet.

Thus in this study we performed experiments on the regulation of glucose uptake, transcription of genes involved in glycolysis, and regulation of miRNAs by the PI3K/AKT/ mTOR pathway, c-MYC and different MAPK signaling pathways. Moreover, we studied the effect of 2-deoxyD-glucose (2-DG), a glucose analogue that decreases glycolytic rate by inhibiting $\mathrm{HK}$, as a single agent and in combination with inhibitors of the c-MYC-, PI3K-, and MAPK signaling pathway inhibitors on cell viability.

\section{Methods \\ Compounds and chemicals}

The c-MYC-Inhibitor 10058-F4 [23], the p38-MAPK inhibitor SB203580 and the GLUT inhibitor phloretin were from Selleck Chemicals (Houston, TX, USA). The PI3K inhibitor LY294002, the mTOR inhibitor Rapamycin and the mitogen-activated protein kinase kinase (MEK) inhibitor PD98059 were from Merck-Millipore 
(Darmstadt, Germany). The GLUT inhibitor cytochalasin $\mathrm{B}$ and $\mathrm{CoCl}_{2}$ were from Sigma Aldrich (St. Louis, MO, USA). They were stored in $10 \mathrm{mM}$ aliquots in DMSO at $-20{ }^{\circ} \mathrm{C}$ and further diluted in the appropriate medium. 2-deoxy-D-glucose (2-DG) was from Sigma-Aldrich and was dissolved in water and stored as $1 \mathrm{M}$ aliquots at $-20^{\circ} \mathrm{C}$.

\section{Cell lines and cell culture}

Established human lymphoma cell lines BJAB, OCI-LY3 and SU-DHL-6 were used in this study. BJAB cells were derived from a Burkitt lymphoma, SU-DHL-6 cells from a follicular B cell lymphoma and OCI-LY3 cells from a DLBCL. The BJAB and SU-DHL-6 cell lines were classified as germinal center B cell like (GCB), OCI-LY3 cells were classified as activated $B$ cell like (ABC) [24]. Cell lines were purchased from ATCC (Manassas, VA, USA) and DSMZ (Braunschweig, Germany). Cell lines were maintained in their appropriate media supplemented with $10 \%$ fetal bovine serum (FBS, Thermo Fisher, Waltham, MA, USA) at $37^{\circ} \mathrm{C}$ at $5 \% \mathrm{CO}_{2}$.

\section{FDG uptake studies and protein determination}

$3 \times 10^{5}$ cells were seeded into each well of a 24 well plate in their appropriate medium containing $0.5 \% \mathrm{FBS}$ and the inhibitors and concentrations indicated. After incubation for $24 \mathrm{~h}$, cells were harvested by centrifugation and resuspended in glucose-free RPMI medium (Thermo Fisher) supplemented with $5.5 \mathrm{mM}$ glucose [25] and 0.5\% FBS and the inhibitors indicated. After $30 \mathrm{~min}, 100 \mathrm{kBq}$ of FDG was added to the cells and samples were incubated for the indicated times or for $30 \mathrm{~min}$ at $37^{\circ} \mathrm{C}$. The cell suspension was pipetted onto a Costar SpinX centrifuge tube filter column $(0.45 \mu \mathrm{m}$, Corning, Corning, NY, USA) and centrifuged for $1 \mathrm{~min}$ at $4{ }^{\circ} \mathrm{C}$ to retain the cells with the incorporated radioactivity. The flow through was discarded and cells were washed two times with cold PBS. Cell-bound radioactivity was measured with a gamma counter (2480 Automatic Gamma Counter Wizard ${ }^{2}$ 3, Perkin Elmer, Waltham, MA, USA). A parallel plate was treated in the same way and cells were harvested and lysed in cell lysis buffer (Cell Signaling Technology, Danvers, MA, USA) for. The lysates were centrifuged at $10,000 \times g$ for $10 \mathrm{~min}$ at $4{ }^{\circ} \mathrm{C}$ and the protein concentrations of supernatants were determined with a modified Bradford assay (Bio-Rad Laboratories, Hercules, CA, USA).

\section{RNA and micro RNA isolation and RT-PCR}

RNA and miRNA were isolated from the same sample using the RNeasy MinElute Cleanup Kit and the miRNA Kit (Qiagen, Hilden, Germany). In brief, $2 \times 10^{6}$ cells were seeded in each well of a six well plate and incubated with the inhibitors and concentrations indicated for $24 \mathrm{~h}$. After centrifugation $(300 \times g, 5 \mathrm{~min})$, the cells were lysed with Qiazol lysis reagent (Qiagen) and RNA > 200 nucleotides and small RNAs were isolated separately according to the instructions of the manufacturer.

$700 \mathrm{ng}$ of RNA were reverse transcribed in a $20 \mu \mathrm{l}$ reaction using the QuantiTect RT Kit (Qiagen). For reverse transcription of miRNA, the equivalent volume to $2 \mu \mathrm{g}$ RNA was incubated with specific primers (Thermo Fisher) and transcribed with the TaqMan miRNA RTKit (Thermo Fisher) in a $15 \mu \mathrm{l}$ reaction. PCR analyses of reversed transcribed RNA and miRNA were performed using $2 \mu \mathrm{l}$ of the RT reaction in a $20 \mu \mathrm{l}$ PCR reaction with the 2x TaqMan Universal Master Mix (Thermo Fisher) and TaqMan Gene Expression Assays or TaqMan MicroRNA Assays (Thermo Fisher) on a Step One Plus real time PCR system (Thermo Fisher). For identification of a suitable reference gene, TaqMan array plates with 47 endogenous control gene candidates (Thermo Fisher) were used on the same instrumentation. Amplifications were performed with the following temperature profile: 5 min initial denaturation at $94{ }^{\circ} \mathrm{C}$, followed 45 cycles of denaturation at $94{ }^{\circ} \mathrm{C}$ for $30 \mathrm{~s}$ and combined primer annealing and extension at $60{ }^{\circ} \mathrm{C}$ for $1 \mathrm{~min}$. Fluorescence intensity of FAM was automatically determined during PCR, with ROX as the passive reference. All experiments were performed at least three times and all samples were amplified in triplicate. CT (cycle threshold) values were calculated with the Step One Plus software tool (Thermo Fisher). The $\Delta \Delta C T$ method [26] was used to calculate changes of cDNA levels compared to untreated control and corrected to a reference gene. Excel 2010 (Microsoft, Redmont, WA, USA) was used to calculate mean CT values of the untreated and treated samples \pm standard deviations $\left(\mathrm{s}_{1}\right.$ and $\left.\mathrm{s}_{2}\right)$, the $\Delta \mathrm{CT}$ value \pm standard deviation $\left(\mathrm{s}=\mathrm{s}_{1}^{2}+\mathrm{s}_{2}^{2}\right)^{1 / 2}$ and the $\Delta \Delta \mathrm{CT}$ value \pm standard deviation. Statistical differences between two groups were assessed with the Mann-Whitney test using SPSS (IBM Inc, Armonk, NY, USA); $\mathrm{p}<0.05$ were considered statistically significant.

\section{Cell survival studies}

For cell survival studies, $5 \times 10^{4}$ cells were seeded into each well of 96-well plates in culture medium with $0.5 \%$ FBS containing the indicated concentrations of inhibitors or a combination of two substances as indicated. After $48 \mathrm{~h}$, viable cells were stained with the Cell Titer Aqueous One Solution assay (Promega, Madison, WI, USA). Optical density at $490 \mathrm{~nm}$ was measured with an Emax microplate photometer (Molecular Devices, Sunnyvale, CA, USA). Control values without treatment were performed as 22-fold determinations, while all concentrations of inhibitors were tested in eightfold. Calculation of results 
and Student's t-test were performed using SoftMax pro software (Molecular Devices), and IC50 values were calculated using Sigma Plot software (Systat, San Jose, CA, USA). Interaction of 2-DG with inhibitors was calculated according to the method of Drewinko et al. [27] using the following formula: $\mathrm{Cl}=($ survival a $\times$ survival $\mathrm{b}) /$ (survival $(a+b) * 100)$, where $a$ and $b$ indicate the two drugs used and $a+b$ indicates the combination of $a$ and b. The interaction was interpreted on the basis of $\mathrm{Cl}$ values where $\mathrm{Cl}>1.05$ indicates synergism, $0.95 \leq \mathrm{Cl} \leq 1.05$ indicates additivity and $\mathrm{Cl}<0.95$ indicates antagonism.

\section{Results}

\section{FDG uptake in lymphoma cell lines}

To characterize the kinetics of FDG uptake in the cells we performed experiments with increasing durations of incubation from $2 \mathrm{~min}$ up to $2 \mathrm{~h}$. Results of all three cell lines are shown in Fig. 1. We found that for up to 30 min, FDG uptake, expressed as counts per $\mu \mathrm{g}$ total protein, increased strongly in all three cell lines. After $30 \mathrm{~min}$, uptake increased up to 60 and $120 \mathrm{~min}$, but with a much lower rate (Fig. 1). We therefore decided to perform further experiments with an FDG incubation time of $30 \mathrm{~min}$. FDG uptake per $\mu \mathrm{g}$ protein was comparable in BJAB and OCI-LY3 cells (182.1 and 197.5 counts per $\mu \mathrm{g}$ protein after $30 \mathrm{~min}$ of incubation), while SU-DHL-6 cells showed a significantly higher uptake ( $\mathrm{p}<0.05 ; 288.7$ counts per $\mu$ g protein; Fig. 1). The reasons for the higher FDG uptake per $\mu$ g protein in SU-DHL-6 is not known but may be due to the smaller size of SU-DHL- 6 cells or to different expression of GLUTs.

To evaluate the specificity of FDG uptake experiments, we next determined the effect of the GLUT1 inhibitors cytochalasin B and phloretin as well as the glycolysis inhibitor 2-DG and, as a positive control, $\mathrm{CoCl}_{2}$ which induces GLUT1 expression (Fig. 2). $\mathrm{CoCl}_{2}$ was found to be toxic to the cells and thus used only for $30 \mathrm{~min}$ before FDG was added. FDG uptake in cells treated with GLUT1 inhibitors was significantly lower than in untreated cells in all three cell lines indicating the important role of GLUT1 transporter in FDG uptake in the lymphoma cells. Incubation with $\mathrm{CoCl}_{2}$ for 30 min significantly increased FDG uptake in all three lymphoma cell lines as expected (Fig. 2). Incubation with 2-DG as a competitor of FDG significantly decreased uptake of FDG as expected (Fig. 2). Taken together, these experiments confirmed the specificity of FDG uptake in our lymphoma cells.

The effect of an inhibition of c-MYC (c-MYC inhibitor 10058-F4), PI3K (LY294002), mTOR (Rapamycin), p38-MAPK (SB203580) and MEK (PD98059) was investigated by incubation of the three cell lines with specific inhibitors of these signaling pathways. Concentrations

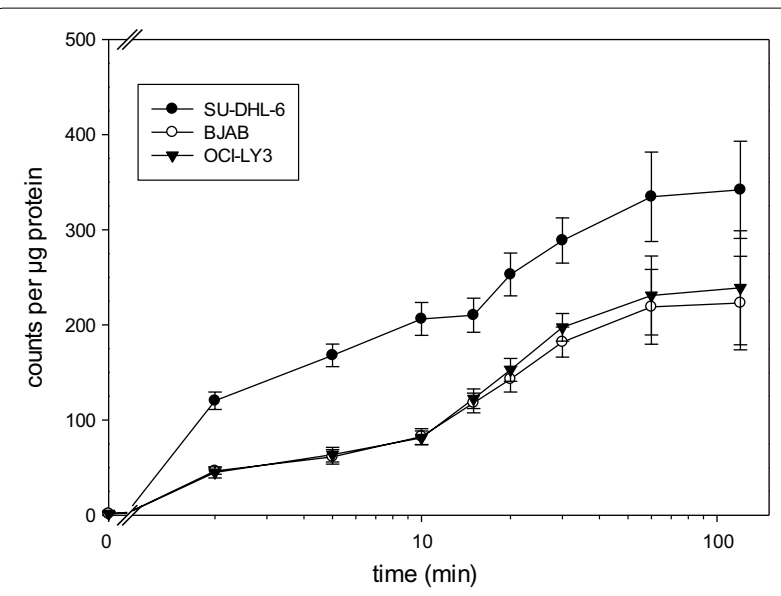

Fig. 1 Time-dependent FDG uptake in BJAB, OCI-LY3 and SU-DHL-6 lymphoma cells. Cells were incubated with $100 \mathrm{kBq}$ of FDG for the indicated times and washed as described. Cell-bound radioactivity was normalized to protein concentration determined from a parallel sample. Values represent mean \pm standard deviation from fourfold determinations

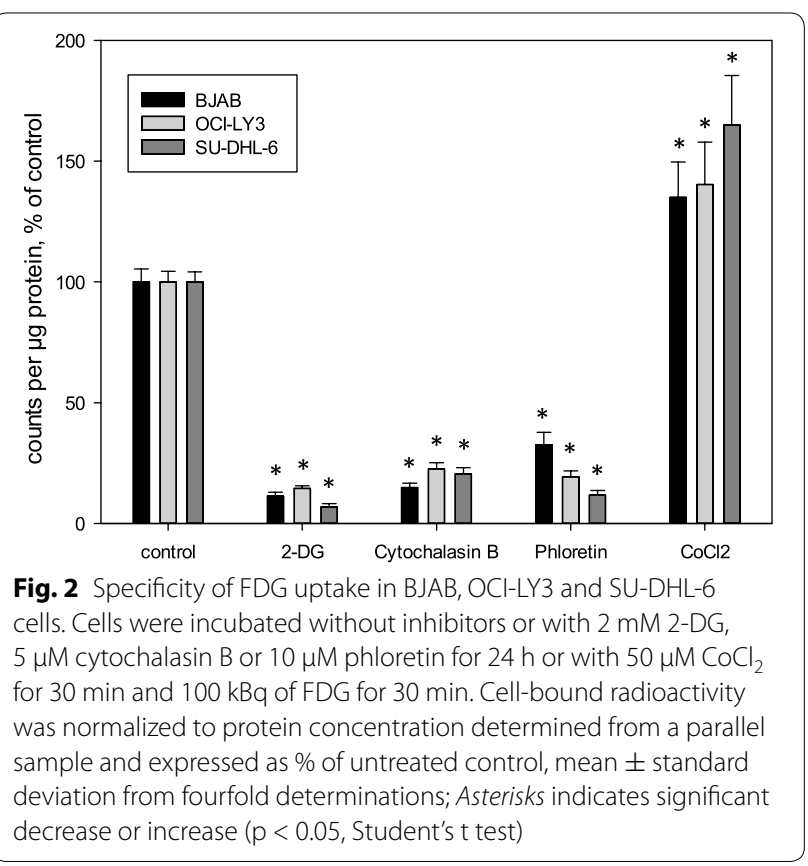

were chosen approx. half the concentrations of IC50 values in proliferation assays (Table 3). While incubation with inhibitors of MAPK (SB203580 as an inhibitor of p38 MAPK and PD98059 as an inhibitor of MEK) had no significant effect on FDG uptake in all three lymphoma cell lines, inhibition of c-MYC (10058-F4), PI3K (LY294002) and mTOR (Rapamycin) led to a significant decrease in FDG uptake (Fig. 3). For the c-MYC inhibitor, the lowest effect with $37.8 \%$ of control was observed in BJAB cells, while SU-DHL-6 cells exhibited the most 


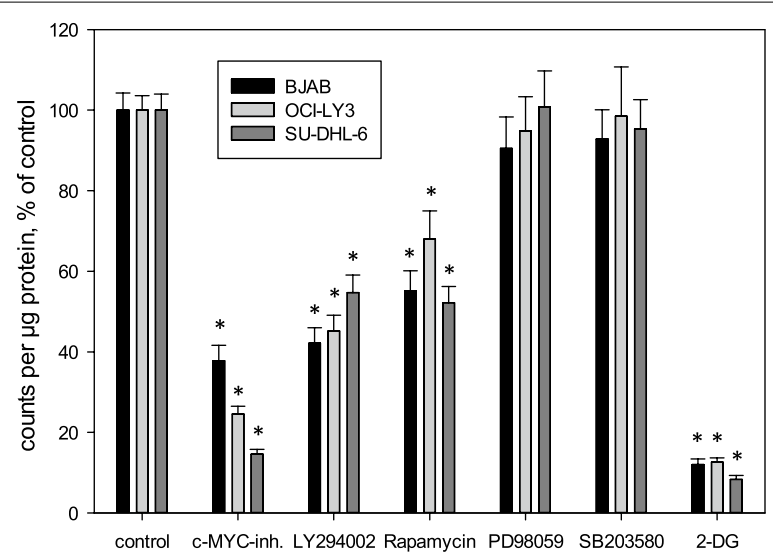

Fig. 3 Decreased FDG uptake in BJAB, OCl-LY3 and SU-DHL-6 cells

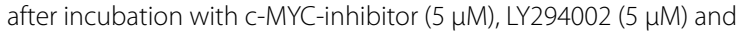
Rapamycin (500 nM) but not after incubation with PD98059 (10 $\mu \mathrm{M})$ and SB203580 (10 $\mu \mathrm{M})$. Cells were incubated without inhibitors or with the inhibitors indicated for $24 \mathrm{~h}$ and $100 \mathrm{kBq}$ of FDG was added for $30 \mathrm{~min}$. Cell-bound radioactivity was normalized to protein concentration determined from a parallel sample. Results are expressed as $\%$ of untreated control, mean \pm standard deviation from fourfold determinations; Asterisks indicates significant decrease $(p<0.05$, Student's t test). Results of an incubation with 2-DG (2 mM) are shown as control

distinct effect (14.6\% of control) and FDG uptake in OCI-LY3 cell was modestly decreased (24.6\% of control; Fig. 3). LY294002 and Rapamycin also led to a significant decrease of FDG uptake in all three cell lines (Fig. 3). In contrast to c-MYC inhibition, the effect of LY294002 and Rapamycin was most distinct in BJAB cells (42.1 and $55.1 \%$ of control) while OCI-LY3 and SUDHL-6 cells showed a significant decrease compared to untreated controls, but to a lesser extent than BJAB cells (LY294002: OCI-LY3 cells 45.2\%; SU-DHL-6 cells 54.7\% of control; Rapamycin: OCI-LY3 cells 68.0\%; SU-DHL-6 cells $52.2 \%$ of control; Fig. 3). As a control, 2-DG led to a decrease of FDG uptake to values around $10 \%$ of control in all three cell lines (Fig. 3).

\section{PCR analyses}

In order to identify a reference gene that is not regulated by our experimental treatment and thus suitable for normalization in real-time PCR assays, we used TaqMan array plates each with 47 endogenous control gene candidates. cDNA from untreated BJAB cells as well as cDNA from BJAB cells treated with the c-MYC inhibitor, LY294002 and Rapamycin was analyzed using the array plates. The hypoxanthine phosphoribosyltransferase 1 (HPRT1) gene showed the lowest regulation of all endogenous control gene candidates analyzed (less than 5\% up and downregulation after each of the three treatments compared to untreated control) and was chosen as the most suitable reference gene for the cDNA measurements. For SB203580 and PD294002 treatments as well as in OCI-LY3 and SU-DHL-6 cells, the suitability of the HPRT1 gene as reference gene was verified within the following PCR analyses. All deviations compared to untreated controls were $<8 \%$.

For miRNA normalization, six candidate miRNAs (U6, RNU48, miR16, miR24, miR26a and miR28-5p) were selected that were shown to be not regulated in other cell models $[28,29]$. All six miRNAs were analyzed within the PCR assays. U6 was found to be the miRNA least regulated ( $<8 \%$ compared to control in all three cell lines analyzed and all treatments).

To ensure similar PCR efficiencies as a prerequisite for relative quantification with the $\Delta \Delta C \mathrm{~T}$ method, PCR efficiency of each primer and probe set was first determined by measuring serial tenfold dilutions of two templates. PCR efficiency was calculated according to the equation: PCR efficacy $=\left(10^{[-1 / \text { slope }]}-1\right) * 100$ [30]. All PCR assays had an efficiency of $>95 \%(96-101 \%)$ as described by the manufacturer.

We first analyzed mRNA expression of the GLUT1 gene after incubation with the five inhibitors. Incubation with the c-MYC inhibitor and the mTOR inhibitor Rapamycin after $24 \mathrm{~h}$ led to a significant down-regulation of GLUT1 mRNA in all three cell lines (Table 1). LY294002 did not affect expression of GLUT1 mRNA (Table 1). Incubation with the MEK inhibitor PD98059 and the p38 MAPK inhibitor SB203580 did not change expression of the GLUT1 mRNAs significantly (Table 1).

Treatment with the c-MYC inhibitor in all three cell lines increased expression of HK2 mRNA (Table 1). After incubation with Rapamycin, expression of HK2 mRNA was decreased in all three cell lines, while LY294002 had no significant effect on HK2 mRNA (Table 1). Incubation PD98059 and SB203580 did not change expression of HK2 mRNA significantly (Table 1).

Lactate dehydrogenase A (LDHA) expression was significantly decreased by the c-MYC inhibitor, Rapamycin and LY294002 in all three cell lines (Table 1). In SU-DHL-6 cells PD98059 incubation led to a slight, but significant decrease in LDHA mRNA expression, while expression of LDHA was not significantly affected by PD98059 in the other cells. Treatment with SB 203580 did not affect mRNA levels of LDHA in all three cell lines (Table 1).

Glucose-6-phosphatase (G6Pase) expression was found to be positively regulated by the c-MYC inhibitor, Rapamycin and LY294002 in all three cell lines. PD98059 incubation led to an increase only in $\mathrm{BJAB}$ cells, while G6Pase mRNA remained unchanged after this treatment in SU-DHL-6 and OCI-LY3 cells. SB203580 incubation did not affect G6Pase mRNA expression in all three cell lines (Table 1). 
Table 1 Changes of mRNA expression in BJAB, OCI-LY3 and SU-DHL-6 cells after incubation with the c-MYC-inhibitor $(5 \mu \mathrm{M})$, LY294002 (5 $\mu \mathrm{M})$, Rapamycin (500 nM), PD98059 (10 $\mu \mathrm{M})$ and SB203580 (10 $\mu \mathrm{M})$ for $24 \mathrm{~h}$

\begin{tabular}{|c|c|c|c|c|}
\hline & GLUT1 & HK2 & G6Ptase & LDHA \\
\hline \multicolumn{5}{|l|}{ BJAB cells } \\
\hline \multicolumn{5}{|l|}{ c-MYC-inh. } \\
\hline$\triangle \triangle C T$ & $1.71 \pm 0.11 \downarrow$ & $-0.45 \pm 0.16 \uparrow$ & $-1.69 \pm 0.14 \uparrow$ & $1.09 \pm 0.14 \downarrow$ \\
\hline Fold of untreated & $0.31(0.28-0.33)^{*}$ & $1.37(1.22-1.53)^{*}$ & $3.23(2.93-3.56)^{*}$ & $0.47(0.43-0.52)^{*}$ \\
\hline \multicolumn{5}{|l|}{ LY294002 } \\
\hline$\triangle \Delta C \mathrm{~T}$ & $0.03 \pm 0.10$ & $0.08 \pm 0.09$ & $-0.41 \pm 0.10 \uparrow$ & $1.24 \pm 0.17 \downarrow$ \\
\hline Fold of untreated & $0.98(0.91-1.06)$ & $0.95(0.89-1.01)$ & $1.33(1.24-1.42)^{*}$ & $0.42(0.38-0.48)^{*}$ \\
\hline \multicolumn{5}{|l|}{ Rapamycin } \\
\hline$\triangle \triangle C T$ & $0.78 \pm 0.09 \downarrow$ & $0.84 \pm 0.08 \downarrow$ & $-0.72 \pm 0.17 \uparrow$ & $1.33 \pm 0.14 \downarrow$ \\
\hline Fold of untreated & $0.58(0.55-0.62)^{*}$ & $0.56(0.53-0.59)^{*}$ & $1.65(1.46-1.85)^{*}$ & $0.40(0.36-0.44)^{*}$ \\
\hline \multicolumn{5}{|l|}{ PD98059 } \\
\hline$\triangle \triangle C T$ & $-0.02 \pm 0.13$ & $0.01 \pm 0.10$ & $-0.45 \pm 0.09 \uparrow$ & $0.04 \pm 0.10$ \\
\hline Fold of untreated & $1.01(0.93-1.11)$ & $0.99(0.93-1.06)$ & $1.37(1.28-1.45)^{*}$ & $0.97(0.91-1.04)$ \\
\hline \multicolumn{5}{|l|}{ SB203580 } \\
\hline$\triangle \triangle C T$ & $0.01 \pm 0.08$ & $-0.02 \pm 0.07$ & $0.05 \pm 0.11$ & $-0.09 \pm 0.12$ \\
\hline Fold of untreated & $0.99(0.94-1.05)$ & $1.01(0.97-1.06)$ & $0.97(0.90-1.04)$ & $1.06(0.98-1.16)$ \\
\hline \multicolumn{5}{|l|}{ OCI-LY3 cells } \\
\hline \multicolumn{5}{|l|}{ c-MYC-inh. } \\
\hline$\triangle \triangle C T$ & $1.12 \pm 0.14 \downarrow$ & $-0.43 \pm 0.12 \uparrow$ & $-1.23 \pm 0.17 \uparrow$ & $0.78 \pm 0.12 \downarrow$ \\
\hline Fold of untreated & $0.46(0.42-0.51)^{*}$ & $1.35(1.24-1.46)^{*}$ & $2.35(2.08-2.64)^{*}$ & $0.58(0.54-0.63)^{*}$ \\
\hline \multicolumn{5}{|l|}{ LY294002 } \\
\hline$\triangle \triangle C T$ & $0.13 \pm 0.15$ & $-0.04 \pm 0.10$ & $-0.60 \pm 0.10 \uparrow$ & $1.03 \pm 0.14 \downarrow$ \\
\hline Fold of untreated & $0.91(0.82-1.01)$ & $1.03(0.96-1.10)$ & $1.52(1.41-1.62)^{*}$ & $0.49(0.44-0.54)^{*}$ \\
\hline \multicolumn{5}{|l|}{ Rapamycin } \\
\hline$\triangle \triangle C T$ & $0.49 \pm 0.13 \downarrow$ & $0.98 \pm 0.15 \downarrow$ & $-0.97 \pm 0.10 \uparrow$ & $1.56 \pm 0.20 \downarrow$ \\
\hline Fold of untreated & $0.71(0.65-0.78)^{*}$ & $0.51(0.46-0.56)^{*}$ & $1.96(1.83-2.10)^{*}$ & $0.34(0.30-0.39)^{*}$ \\
\hline \multicolumn{5}{|l|}{ PD98059 } \\
\hline$\triangle \triangle C T$ & $-0.03 \pm 0.18$ & $0.01 \pm 0.13$ & $-0.03 \pm 0.08$ & $0.01 \pm 0.16$ \\
\hline Fold of untreated & $1.02(0.90-1.16)$ & $0.99(0.91-1.09)$ & $1.02(0.97-1.08)$ & $0.99(0.89-1.11)$ \\
\hline \multicolumn{5}{|l|}{ SB203580 } \\
\hline$\triangle \triangle C T$ & $0.16 \pm 0.14$ & $0.44 \pm 0.12 \downarrow$ & $-0.08 \pm 0.13$ & $-0.03 \pm 0.08$ \\
\hline Fold of untreated & $0.90(0.81-0.99)$ & $0.74(0.68-0.80)^{*}$ & $1.06(0.97-1.16)$ & $1.02(0.97-1.08)$ \\
\hline \multicolumn{5}{|l|}{$\underline{\text { SU-DHL-6 cells }}$} \\
\hline \multicolumn{5}{|l|}{ c-MYC-inh. } \\
\hline$\triangle \Delta C T$ & $1.23 \pm 0.12 \downarrow$ & $-0.36 \pm 0.07 \uparrow$ & $-0.93 \pm 0.12 \uparrow$ & $1.19 \pm 0.08 \downarrow$ \\
\hline Fold of untreated & $0.43(0.39-0.46)^{*}$ & $1.28(1.22-1.35)^{*}$ & $1.91(1.75-2.07)^{*}$ & $0.44(0.41-0.46)^{*}$ \\
\hline \multicolumn{5}{|l|}{ LY294002 } \\
\hline$\triangle \triangle C T$ & $-0.11 \pm 0.11$ & $-0.05 \pm 0.14$ & $0.51 \pm 0.08 \uparrow$ & $0.98 \pm 0.11 \downarrow$ \\
\hline Fold of untreated & $1.08(1.00-1.16)$ & $1.04(0.94-1.14)$ & $1.42(1.35-1.51)^{*}$ & $0.51(0.47-0.55)^{*}$ \\
\hline \multicolumn{5}{|l|}{ Rapamycin } \\
\hline$\triangle \triangle C T$ & $0.66 \pm 0.09 \downarrow$ & $-0.83 \pm 0.16 \downarrow$ & $-0.82 \pm 0.16 \uparrow$ & $0.85 \pm 0.09 \downarrow$ \\
\hline Fold of untreated & $0.63(0.59-0.67)^{*}$ & $0.56(0.50-0.63)^{*}$ & $1.77(1.58-1.97)^{*}$ & $0.55(0.52-0.59)^{*}$ \\
\hline \multicolumn{5}{|l|}{ PD98059 } \\
\hline$\triangle \triangle C T$ & $0.04 \pm 0.16$ & $0.09 \pm 0.11$ & $-0.05 \pm 0.13$ & $0.30 \pm 0.10 \downarrow$ \\
\hline Fold of untreated & $0.97(0.87-1.09)$ & $0.94(0.87-1.01)$ & $1.04(0.95-1.13)$ & $0.81(0.76-0.87)^{*}$ \\
\hline \multicolumn{5}{|l|}{ SB203580 } \\
\hline$\triangle \triangle C T$ & $-0.08 \pm 0.15$ & $0.05 \pm 0.09$ & $0.14 \pm 0.14$ & $0.17 \pm 0.17$ \\
\hline Fold of untreated & $1.06(0.95-1.17)$ & $0.97(0.91-1.03)$ & $0.91(0.82-1.00)$ & $0.89(0.79-1.00)$ \\
\hline
\end{tabular}

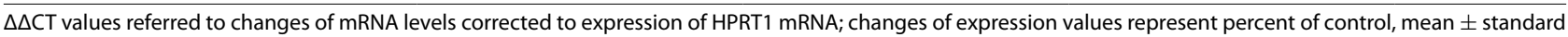
deviation from threefold determinations

* and arrows indicate significant changes $(p<0.05$, Mann-Whitney test) 
miRNA21 expression was diminished by the c-MYC inhibitor and Rapamycin in all three cell lines, while LY294002 incubation led to a decrease in miRNA21 only in BJAB and OCI-LY3 cells (Table 2). miRNA21 expression was not significantly influenced by treatment with PD98059 and SB203580 (Table 2).

Expression of miRNA23a was not significantly influenced by the five inhibitors used here. miRNA133a was diminished by the c-MYC inhibitor and LY294002 and increased by Rapamycin and PD98059 in BJAB and OCILY3 cells, while in SU-DHL-6 cells miRNA133a expression was increased by the c-MYC inhibitor and not affected by the other inhibitors (Table 2).

For miRNA133b-, -138-1- and -143 expression, SUDHL-6 cells also showed an expression pattern distinct from that in BJAB and OCI-LY3 cells: miRNA133b was increased after treatment with the c-MYC inhibitor, Rapamycin, LY294002 and PD98059, while SB203580 had no significant effect in BJAB and OCI-LY3 cells. In SU-DHL-6 cells, only the c-MYC inhibitor and Rapamycin led to a significant increase in miRNA133b, while LY294002 treatment decreased miRNA133b expression and PD98059 and SB203580 incubation had no effect on miRNA133b (Table 2).

miRNA138-1 expression was not affected by all five inhibitors in SU-DHL-6 cells, while in BJAB and OCILY3 cells treatment with the c-MYC inhibitor, Rapamycin and LY294002 resulted in an increased expression of miRNA138-1. PD98059 also increased miRNA138-1 in BJAB cells but not in OCI-LY3 cells, while incubation with SB203580 had no significant effect (Table 2).

miRNA143 was not expressed in SU-DHL-6 cells. In BJAB and OCI-LY3 cells, miRNA143 showed no regulation after incubation with all five inhibitors (Table 2).

miRNA195-5p was regulated non-uniformly in the three cell lines: in BJAB cells it was upregulated by LY294002, in OCI-LY3 cells it was upregulated by PD98059 and SB203580 and downregulated by LY294002, while in SU-DHL-6 cells it was downregulated by the c-MYC inhibitor (Table 2).

\section{The c-MYC inhibitor, LY294002, Rapamycin and 2-DG decreased viability of lymphoma cells}

The three lymphoma cell lines were treated with increasing concentrations of the c-MYC inhibitor, LY294002, Rapamycin, SB203580, PD98059 as well as with 2-DG or vehicle for $48 \mathrm{~h}$ and the percentage of viable cells compared to controls was assessed. Treatment with SB203580 and PD98059 with concentrations up to $50 \mu \mathrm{M}$ had no significant effect on survival of all three cell lines (Fig. 4d, e; Table 3). In contrast, incubation with the c-MYC inhibitor decreased the number of viable cells in all cell lines examined with OCI-LY3 being the most sensitive cell line (IC50 values: $10.23 \mu \mathrm{M}$ for BJAB; $6.48 \mu \mathrm{m}$ for OCI-LY3 and $6.67 \mu \mathrm{M}$ for SU-DHL-6; Fig. 4a; Table 3). LY294002 also significantly decreased the number of viable cells in all three cell lines with IC50 values in the same range in the three cell lines (BJAB: $10.66 \mu \mathrm{M}$; OCI-LY3: $9.67 \mu \mathrm{M}$; SU-DHL-6: 10.94 $\mu$ M; Fig. 4b; Table 3). Rapamycin was also effective with similar IC50 values in all three lymphoma cell lines (BJAB: $1021 \mathrm{nM}$; OCI-LY3: $912 \mathrm{nM}$; SUDHL-6: 1208 nM; Fig. 4c; Table 3).

Cell viability of all three cell lines was inhibited after incubation with 2-DG, an inhibitor of hexokinase, with the SU-DHL-6 cell line being the most sensitive cell line (IC50: BJAB: 4.65 mM; OCI-LY3: 4.073 mM; SU-DHL-6: 2.86 mM; Fig. 4f; Table 3).

\section{Synergistic action of 2-DG with inhibitors}

The effects of a combined treatment of the three lymphoma cell lines with 2-DG and the signaling pathways inhibitors on the survival rates were investigated to study the possibility of a synergistic effect. The results are shown in Table 4. Calculation of survival rates according to the method of Drewinko et al. [27] yielded synergistic effects $(\mathrm{Cl}$ values $>1.05)$ in all three cell lines for the combination of 2-DG with the c-MYC-inhibitor 10058F4 and with LY294002 (Table 4a, b), while for the combination of 2-DG with Rapamycin the BJAB and SU-DHL-6 cells showed synergistic effects and OCI-LY3 cells had an additive effect (Table 4c). Interestingly, we observed also synergistic effects of 2-DG with the p38 MAPK inhibitor SB203580 in all three cell lines (Table 4e), though SB203580 alone had no effects on viability of cells (Fig. 4d). The combination of 2-DG and PD98059 was synergistic in OCI-LY3 cells and had additive effects in BJAB and SU-DHL-6 cells (Table 4d). No antagonistic effect was observed (Table 4).

\section{Discussion}

In this study we showed regulation of glucose uptake by c-MYC- and PI3K/AKT/mTOR dependent pathways in lymphoma cell lines and demonstrated evidence for the altered glucose metabolism as a potential target to improve inhibitor-based therapeutic approaches in these cells.

During tumorigenesis, a change in energy metabolism of the tumor cells occurs and deregulated metabolism of glucose is one hallmark of cancer [31]. The exact molecular mechanisms leading to this altered phenotype of cancer cells remain unclear. Besides hypoxia, activation of oncogenes and inactivation of tumor suppressor genes, alterations in the cellular signaling network are involved in the glycolytic switch in cancer cells [Review: 32]. 
Table 2 Changes of miRNA expression in BJAB, OCI-LY3 and SU-DHL-6 cells after incubation with the C-MYC-inhibitor $(5 \mu \mathrm{M})$, LY294002 (5 $\mu \mathrm{M})$, Rapamycin (500 nM), PD98059 (10 $\mu \mathrm{M})$ and SB203580 (10 $\mu \mathrm{M})$ for $24 \mathrm{~h}$

\begin{tabular}{|c|c|c|c|c|c|c|}
\hline & $\operatorname{miR21}$ & miR23a & miR133a & miR133b & miR138-1 & $\operatorname{miR} 143$ \\
\hline \multicolumn{7}{|l|}{$\underline{B J A B}$ cells } \\
\hline \multicolumn{7}{|l|}{$c-M Y C-i n h$} \\
\hline$\triangle \triangle \mathrm{CT}$ & $1.78 \pm 0.13 \downarrow$ & $0.16 \pm 0.11$ & $0.80 \pm 0.14 \downarrow$ & $-0.89 \pm 0.14 \uparrow$ & $-1.68 \pm 0.17 \uparrow$ & $-0.12 \pm 0.14$ \\
\hline Fold of untreated & $0.29(0.27-0.32)^{*}$ & $0.90(0.83-0.97)$ & $0.57(0.54-0.61)^{*}$ & $1.85(1.68-2.04)^{*}$ & $3.20(2.85-3.61)^{*}$ & $1.09(0.99-1.20)$ \\
\hline \multicolumn{7}{|l|}{ LY294002 } \\
\hline$\triangle \triangle C T$ & $1.06 \pm 0.18 \downarrow$ & $0.21 \pm 0.19$ & $1.02 \pm 0.20 \downarrow$ & $0.52 \pm 0.12 \uparrow$ & $-0.54 \pm 0.09 \uparrow$ & $0.06 \pm 0.11$ \\
\hline Fold of untreated & $0.48(0.42-0.54)^{*}$ & $0.86(0.76-0.99)$ & $0.49(0.43-0.57)^{*}$ & $1.43(1.32-1.56)^{*}$ & $1.45(1.37-1.55)^{*}$ & $0.96(0.89-1.04)$ \\
\hline \multicolumn{7}{|l|}{ Rapamycin } \\
\hline$\triangle \triangle C T$ & $1.28 \pm 0.08 \downarrow$ & $0.27 \pm 0.24$ & $-0.64 \pm 0.15 \uparrow$ & $-0.86 \pm 0.12 \uparrow$ & $-0.53 \pm 0.11 \uparrow$ & $0.21 \pm 0.20$ \\
\hline Fold of untreated & $0.41(0.39-0.44)^{*}$ & $0.83(0.70-0.98)$ & $1.56(1.40-1.73)^{*}$ & $1.82(1.67-1.97)^{*}$ & $1.44(1.34-1.56)^{*}$ & $0.86(0.75-0.99)$ \\
\hline \multicolumn{7}{|l|}{ PD98059 } \\
\hline$\triangle \triangle \mathrm{CT}$ & $0.03 \pm 0.08$ & $-0.04 \pm 0.07$ & $-0.65 \pm 0.12 \uparrow$ & $-0.60 \pm 0.15 \uparrow$ & $-1.51 \pm 0.14 \uparrow$ & $0.05 \pm 0.10$ \\
\hline Fold of untreated & $0.98(0.93-1.04)$ & $1.03(0.98-1.08)$ & $1.57(1.44-1.71)^{*}$ & $1.52(1.37-1.68)^{*}$ & $2.85(2.58-3.14)^{*}$ & $0.97(0.90-1.04)$ \\
\hline \multicolumn{7}{|l|}{ SB203580 } \\
\hline$\triangle \triangle \mathrm{CT}$ & $-0.04 \pm 0.13$ & $-0.01 \pm 0.11$ & $0.03 \pm 0.07$ & $-0.01 \pm 0.07$ & $-0.05 \pm 0.12$ & $0.06 \pm 0.09$ \\
\hline Fold of untreated & $1.03(0.94-1.13)$ & $1.01(0.93-1.09)$ & $0.98(0.93-1.03)$ & $1.01(0.96-1.06)$ & $1.04(0.95-1.13)$ & $0.96(0.90-1.02)$ \\
\hline \multicolumn{7}{|l|}{$\underline{\mathrm{OCl}-\mathrm{LY} 3 \text { cells }}$} \\
\hline \multicolumn{7}{|l|}{$c-M Y C-i n h$} \\
\hline$\triangle \triangle \mathrm{CT}$ & $1.20 \pm 0.15 \downarrow$ & $0.19 \pm 0.17$ & $0.83 \pm 0.12 \downarrow$ & $-0.70 \pm 0.13 \uparrow$ & $-1.47 \pm 0.16 \uparrow$ & $-0.06 \pm 0.11$ \\
\hline Fold of untreated & $0.44(0.39-0.48)^{*}$ & $0.88(0.78-0.99)$ & $0.56(0.52-0.61)^{*}$ & $1.62(1.48-1.78)^{*}$ & $2.77(2.48-3.10)^{*}$ & $1.04(0.97-1.13)$ \\
\hline \multicolumn{7}{|l|}{ LY294002 } \\
\hline$\triangle \triangle \mathrm{CT}$ & $0.76 \pm 0.14 \downarrow$ & $0.05 \pm 0.09$ & $0.61 \pm 0.14 \downarrow$ & $-0.77 \pm 0.13 \uparrow$ & $-0.84 \pm 0.18 \uparrow$ & $0.13 \pm 0.12$ \\
\hline Fold of untreated & $0.59(0.54-0.65)^{*}$ & $0.97(0.91-1.03)$ & $0.66(0.59-0.72)^{*}$ & $1.71(1.56-1.87)^{*}$ & $1.79(1.58-2.03)^{*}$ & $0.91(0.84-0.99)$ \\
\hline \multicolumn{7}{|l|}{ Rapamycin } \\
\hline$\triangle \triangle \mathrm{CT}$ & $1.45 \pm 0.17 \downarrow$ & $0.20 \pm 0.18$ & $-0.80 \pm 0.16 \uparrow$ & $-0.60 \pm 0.10 \uparrow$ & $-0.93 \pm 0.12 \uparrow$ & $-0.02 \pm 0.06$ \\
\hline Fold of untreated & $0.37(0.33-0.41)^{*}$ & $0.87(0.77-0.99)$ & $1.74(1.56-1.95)^{*}$ & $1.52(1.40-1.64)^{*}$ & $1.91(1.75-2.07)^{*}$ & $1.01(0.97-1.06)$ \\
\hline \multicolumn{7}{|l|}{ PD98059 } \\
\hline$\triangle \triangle \mathrm{CT}$ & $-0.04 \pm 0.08$ & $0.26 \pm 0.15$ & $-0.77 \pm 0.13 \uparrow$ & $-0.53 \pm 0.13 \uparrow$ & $0.06 \pm 0.10$ & $-0.14 \pm 0.16$ \\
\hline Fold of untreated & $1.03(0.97-1.09)$ & $0.90(0.81-0.99)$ & $1.71(1.56-1.87)^{*}$ & $1.44(1.32-1.58)^{*}$ & $0.96(0.90-1.03)$ & $1.10(0.99-1.23)$ \\
\hline \multicolumn{7}{|l|}{ SB203580 } \\
\hline$\triangle \triangle C T$ & $0.05 \pm 0.08$ & $-0.05 \pm 0.07$ & $-0.17 \pm 0.15$ & $0.09 \pm 0.13$ & $0.00 \pm 0.09$ & $-0.14 \pm 0.13$ \\
\hline Fold of untreated & $0.97(0.91-1.02)$ & $1.04(0.99-1.09)$ & $0.89(0.80-0.99)$ & $0.94(0.86-1.03)$ & $1.00(0.94-1.06)$ & $1.10(1.01-1.21)$ \\
\hline \multicolumn{7}{|l|}{$\underline{\text { SU-DHL-6 cells }}$} \\
\hline \multicolumn{7}{|l|}{$c-M Y C-i n h$} \\
\hline$\Delta \triangle \mathrm{CT}$ & $0.68 \pm 0.13 \downarrow$ & $-0.03 \pm 0.07$ & ne & $-0.99 \pm 0.17 \uparrow$ & $0.08 \pm 0.11$ & ne \\
\hline Fold of untreated & $0.62(0.57-0.68)^{*}$ & $1.02(0.97-1.07)$ & & $1.99(1.77-2.23)^{*}$ & $0.95(0.81-1.02)$ & \\
\hline \multicolumn{7}{|l|}{ LY294002 } \\
\hline$\triangle \triangle C T$ & $0.12 \pm 0.20$ & $-0.21 \pm 0.24$ & ne & $0.73 \pm 0.10 \downarrow$ & $-0.03 \pm 0.13$ & ne \\
\hline Fold of untreated & $0.92(0.80-1.06)$ & $1.16(0.98-1.37)$ & & $0.60(0.56-0.65)^{*}$ & $1.02(0.93-1.12)$ & \\
\hline \multicolumn{7}{|l|}{ Rapamycin } \\
\hline$\triangle \triangle \mathrm{CT}$ & $1.14 \pm 0.14 \downarrow$ & $0.05 \pm 0.07$ & ne & $-0.77 \pm 0.13 \uparrow$ & $-0.07 \pm 0.11$ & ne \\
\hline Fold of untreated & $0.45(0.41-0.50)^{*}$ & $0.97(0.92-1.01)$ & & $1.71(1.56-1.87)^{*}$ & $1.05(0.97-1.13)$ & \\
\hline \multicolumn{7}{|l|}{ PD98059 } \\
\hline$\triangle \triangle C T$ & $-0.08 \pm 0.14$ & $0.06 \pm 0.07$ & ne & $-0.07 \pm 0.11$ & $-0.01 \pm 0.06$ & ne \\
\hline Fold of untreated & $1.06(0.96-1.16)$ & $0.96(0.91-1.01)$ & & $1.05(0.97-1.13)$ & $1.01(0.97-1.05)$ & \\
\hline \multicolumn{7}{|l|}{ SB203580 } \\
\hline$\triangle \triangle C T$ & $-0.10 \pm 0.09$ & $-0.06 \pm 0.10$ & ne & $0.08 \pm 0.08$ & $0.03 \pm 0.12$ & ne \\
\hline Fold of untreated & $1.07(1.01-1.14)$ & $1.04(0.97-1.12)$ & & $0.95(0.90-1.00)$ & $0.98(0.90-1.06)$ & \\
\hline
\end{tabular}

$\overline{\Delta C T}$ values referred to changes of miRNA levels corrected to expression of U6 miRNA; changes of expression values represent percent of control, mean \pm standard deviation from threefold determinations

* and arrows indicate significant changes $(p<0.05$, Mann-Whitney test)

ne not expressed 

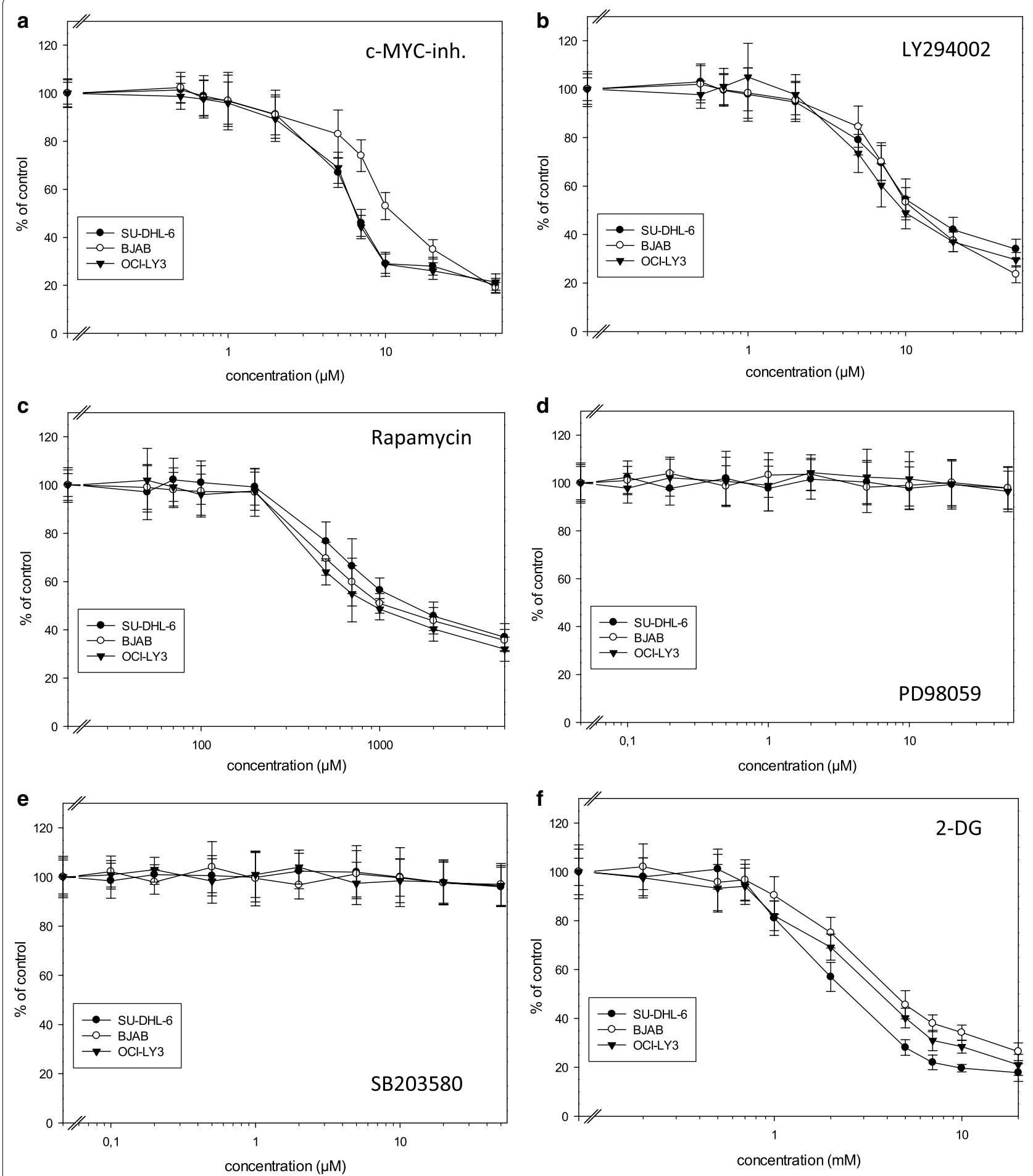

Fig. 4 Decreased viability of BJAB, OCI-LY3 and SU-DHL-6 cells after incubation with the c-MYC-inhibitor (a), LY294002 (b), Rapamycin (c) and 2-DG (f) but not after incubation with PD98059 (d) and SB203580 (e). Cells were cultured in the presence of increasing concentrations of the substances indicated or vehicle control for $48 \mathrm{~h}$ and viability was assessed by MTT assay. Values represent percent of vehicle control, mean \pm standard deviation from eightfold determinations 
Table 3 IC50 values of BJAB, OCI-LY3 and SU-DHL-6 cells after $48 \mathrm{~h}$ of treatment with increasing concentrations of the C-MYC-inhibitor, LY294002, Rapamycin, PD98059, SB203580 and 2-DG (MTT assay)

\begin{tabular}{llll}
\hline & BJAB & OCI-LY3 & SU-DHL-6 \\
\hline c-MYC-inh $(\mu \mathrm{M})$ & 10.23 & 6.48 & 6.67 \\
LY294002 $(\mu \mathrm{M})$ & 10.66 & 9.67 & 10.94 \\
Rapamycin $(\mathrm{nM})$ & 1021 & 912 & 1208 \\
PD98059 $(\mu \mathrm{M})$ & $>50$ & $>50$ & $>50$ \\
SB203580 $(\mu \mathrm{M})$ & $>50$ & $>50$ & $>50$ \\
2-DG $(\mathrm{mM})$ & 4.65 & 4.07 & 2.86 \\
\hline
\end{tabular}

\section{Effects of PI3K/mTOR inhibitors}

The PI3K/AKT/mTOR pathway is altered in many human cancers by activating mutations, aberrant receptor tyrosine kinase signaling or inactivating mutations in tumor suppressor genes like PTEN (phosphatase and tensin homolog) [33, 34]. In NHL, this pathway is often activated, although mutations are only infrequently found [Review: 35]. AKT as a downstream effector of PI3K is known as an important driver of the tumor glycolytic phenotype and renders cancer cells dependent on glycolysis for survival $[9,36]$. AKT stimulates glucose uptake and glycolysis by increasing the expression and membrane translocation of glucose transporter proteins like GLUT1 and by activating glycolytic enzymes and regulating $\mathrm{HK}$ expression, activity and interaction with mitochondria [37]. mTOR is a serine/threonine kinase downstream of PI3K-AKT that acts through the mTOR complexes 1 and 2 (mTORC1 and -2) to induce transcription of many genes involved in altered tumor cell metabolism [38].

Treatment of our NHL cell lines with the PI3K inhibitor LY294002 or the mTOR inhibitor Rapamycin led to a decrease in cell viability in all three cell lines with IC50 values in the range of around $1 \mu \mathrm{M}$ for Rapamycin and $10 \mu \mathrm{M}$ for LY294002 (Fig. 4; Table 1) demonstrating the importance of the PI3K pathway for survival of the

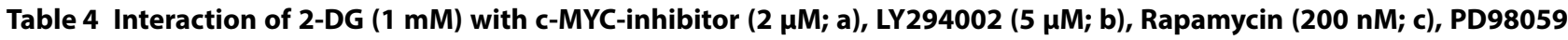
(5 $\mu \mathrm{M}$; d) and SB203580 (5 $\mu \mathrm{M}$; e) in the three lymphoma cell lines

\begin{tabular}{|c|c|c|c|c|}
\hline a cell line & $\begin{array}{l}2-\mathrm{DG} \\
1 \mathrm{mM}\end{array}$ & $\begin{array}{l}\text { c-MYC-inh. } \\
2 \mu \mathrm{M}\end{array}$ & 2-DG + c-MYC-inh. & $\mathrm{Cl}$ \\
\hline$B J A B$ & $89.6 \pm 7.4$ & $91.0 \pm 7.7$ & $57.7 \pm 4.8$ & 1.41 syn. \\
\hline OCI-LY3 & $81.0 \pm 6.6$ & $85.4 \pm 7.3$ & $56.3 \pm 5.5$ & 1.23 syn. \\
\hline SU-DHL-6 & $84.0 \pm 6.3$ & $86.3 \pm 6.4$ & $57.9 \pm 5.1$ & 1.25 syn. \\
\hline b cell line & $\begin{array}{l}\text { 2-DG } \\
1 \mathrm{mM}\end{array}$ & $\begin{array}{l}\text { LY294002 } \\
5 \mu \mathrm{M}\end{array}$ & $2-D G+Y 294002$ & $\mathrm{Cl}$ \\
\hline$B J A B$ & $88,1 \pm 7.0$ & $84.6 \pm 7.0$ & $47.2 \pm 3.5$ & 1.60 syn. \\
\hline OCI-LY3 & $79.0 \pm 7.3$ & $73.7 \pm 6.6$ & $42.6 \pm 4.6$ & 1.37 syn. \\
\hline SU-DHL-6 & $83.5 \pm 6.4$ & $87.9 \pm 8.1$ & $38.2 \pm 3.1$ & 1.92 syn. \\
\hline c cell line & $\begin{array}{l}\text { 2-DG } \\
1 \mathrm{mM}\end{array}$ & $\begin{array}{l}\text { Rapamycin } \\
200 \mathrm{nM}\end{array}$ & 2-DG + Rapamycin & $\mathrm{Cl}$ \\
\hline$B J A B$ & $90.7 \pm 6.8$ & $90.4 \pm 8.3$ & $58.2 \pm 3.7$ & 1.41 syn. \\
\hline OCI-LY3 & $80.5 \pm 6.4$ & $88.9 \pm 7.6$ & $69.5 \pm 5.0$ & $1.03 \mathrm{add}$ \\
\hline SU-DHL-6 & $82.5 \pm 7.6$ & $91.6 \pm 7.9$ & $47.8 \pm 3.4$ & 1.58 syn \\
\hline d cell line & $\begin{array}{l}2-\mathrm{DG} \\
1 \mathrm{mM}\end{array}$ & $\begin{array}{l}\text { PD98059 } \\
5 \mu \mathrm{M}\end{array}$ & 2-DG + PD98059 & $\mathrm{Cl}$ \\
\hline$B J A B$ & $90.3 \pm 8.4$ & $103.7 \pm 9.2$ & $95.7 \pm 7.7$ & 0.98 add. \\
\hline OCI-LY3 & $81.5 \pm 6.8$ & $98.2 \pm 8.5$ & $75.3 \pm 5.6$ & 1.06 syn. \\
\hline SU-DHL-6 & $81.5 \pm 5.8$ & $99.4 \pm 7.8$ & $77.9 \pm 6.5$ & 1.04 add. \\
\hline e cell line & $\begin{array}{l}2-\mathrm{DG} \\
1 \mathrm{mM}\end{array}$ & $\begin{array}{l}\text { SB203580 } \\
5 \mu \mathrm{M}\end{array}$ & $2-D G+$ SB203580 & $\mathrm{Cl}$ \\
\hline$B J A B$ & $91.4 \pm 6.7$ & $102.6 \pm 9.0$ & $83.5 \pm 7.0$ & 1.12 syn. \\
\hline OCI-LY3 & $80.8 \pm 7.4$ & $97.8 \pm 7.6$ & $63,5 \pm 5.3$ & 1.24 syn. \\
\hline SU-DHL-6 & $79.6 \pm 5.7$ & $104.3 \pm 8.4$ & $54.1 \pm 4.5$ & 1.53 syn. \\
\hline
\end{tabular}

MTT assays were performed to determine the viability of cells after incubation with one compound alone or in combination. $\mathrm{Cl}$ values were calculated according to the method of Drewinko et al. (see "Methods"), where $\mathrm{Cl}>1.05$ indicates synergism (syn.), $0.95 \leq \mathrm{Cl} \leq 1.05$ indicates additivity (add.) and $\mathrm{Cl}<0.95$ indicates antagonism 
cells. These findings are in good agreement with recently reported results of Ezell and coworkers [39] who found PI3K and mTOR inhibitors effective in arresting proliferation in DLBCL lines. However, response rates to mTOR inhibitors as single agent therapy in phase II clinical studies are only around $30 \%$ in NHL $[40,41]$.

In addition to the effects on the number of viable cells, both inhibitors led to a decreased FDG uptake after $24 \mathrm{~h}$ treatment as expected (Fig. 3). A similar inhibitory effect of PI3K/mTOR inhibitors on FDG uptake was already described in cervical cancer cells [42] and confirms the well-known importance of the PI3K pathway for enhanced glucose metabolism.

Unexpectedly, while Rapamycin led to a decrease in GLUT1 mRNA expression, treatment with LY294002 did not significantly affect GLUT1 mRNA in all three cell lines (Table 2). This discrepancy between mRNA results and FDG uptake after LY294002 treatment may be due to modifications in protein expression and processing like reduced translocation of GLUT1 and GLUT4 to the cell membrane as described in cervical cancer and lung adenocarcinoma cells $[42,43]$. In cutaneous T-cell lymphoma cells, incubation with Rapamycin decreased glucose uptake in both cell lines investigated, but mRNA expression of glycolysis genes was diminished only in one cell line [44]. These results show that the molecular mechanism by which the PI3K signaling cascade regulates GLUT processing is still not clear and further experiments are needed to elucidate the modulation of expression, translocation and regulation of GLUTs.

The decrease of LDHA mRNA expression as well as the increase in G6Ptase after incubation with LY294002 and Rapamycin in all three cell lines corresponds to a diminished glycolysis after PI3K/AKT/mTOR inhibition, since LDHA is a glycolytic enzyme while G6Ptase catalyzes the reaction from glucose-6-phosphate back to glucose [3].

HK2 mRNA expression was diminished in all three cell lines after incubation with Rapamycin, but not with LY294002. This may reflect the distinct levels of inhibition by the two substances. LY294002 inhibits PI3K, while Rapamycin inhibits mTOR proteins that are located downstream of PI3K and AKT. Treatment with LY294002 may therefore be circumvented by activation of the downstream AKT and mTOR kinases by alternative pathways or mutations and thus may explain the different effects of LY294002 and Rapamycin in our cells [45].

The changes in miRNA expression after treatment with LY294002 or Rapamycin primarily reflect the oncogenic features of the PI3K/mTOR pathway in NHL cells with downregulation of the oncogenic miRNA21 and upregulation of the tumor suppressor miRNAs 133a, -133b and -138-1 (Table 3). Further experiments will show if this regulation is directly related to the diminished expression of the GLUT1 and LDHA genes after inhibition of this pathway and if manipulation of the miRNA level may influence expression of glycolysis-related genes.

\section{Effect of the c-MYC inhibitor}

$\mathrm{c}-\mathrm{MYC}$ is an oncogenic transcription factor that is overexpressed in many cancer types including B- and T-cell malignancies and is involved in cell metabolism and cell proliferation [46]. In lymphoma, c-MYC activation occurs by several molecular mechanisms including translocations, amplification, mutations, altered intracellular localization of the c-MYC protein or miRNA-dependent mechanisms [47-49].

Incubation of our cells with the c-MYC inhibitor as expected led to a decreased number of viable cells (Fig. 4a) with IC50 values $(6.48-10.23 \mu \mathrm{M})$ in the lower range seen in other cell systems (breast cancer cells: 20-30 $\mu \mathrm{M}$ [50]; multiple myeloma cell lines: 12-45 $\mu \mathrm{M}$ [51]; ovarian carcinoma cell lines: 3.2 and $4.4 \mu \mathrm{M}$ [52]; HepG2 hepatocellular carcinoma cells: around $100 \mu \mathrm{M}$ [53]; acute myeloid leukemia (AML) cell lines: 60-90 $\mu \mathrm{M}$ [54]). Thus, the c-MYC inhibitor may be a suitable substance for reducing the number of viable lymphoma cells. Further experiments may reveal the mode of action, e.g. apoptosis induction, inhibition of proliferation and cell cycle arrest as well as its in vivo efficacy in lymphoma.

Besides a reduction of the number of viable cells, treatment of lymphoma cells with the c-MYC inhibitor led to a marked decrease in FDG uptake in all three cell lines with the SU-DHL- 6 cells showing the most pronounced effect (Fig. 3). Corresponding to the decreased FDG uptake, after incubation with the c-MYC inhibitor the expression of GLUT1 mRNA was significantly decreased in all three cell lines (Table 2). Similar effects of a decreased glucose uptake and a diminished expression of GLUT 1 after incubation with the c-MYC inhibitor or after knockdown of c-MYC with siRNA were already described in breast cancer cells [50]. Further experiments are necessary to evaluate protein expression and cellular localization of glucose transporters to determine the cellular effect of an inhibition of c-MYC.

As expected, expression of the mRNA encoding LDHA was also diminished after incubation with the c-MYCinhibitor (Table 2) while expression of HK2 and the G6Pase was enhanced. Targeting of the expression of glycolytic enzymes by c-MYC was already described in other cell systems $[55,56]$. However, while we still do not have an explanation for the increased expression of HK2, enhanced G6Pase expression may be explained similarly as the one after inhibition of the PI3K pathway and may reflect a partly reversed Warburg effect.

The changes in miRNA expression after c-MYC inhibition resemble those after inhibition of PI3K/mTOR 
probably reflecting the function of c-MYC as an oncogene in NHL cells. In contrast to the results obtained after mTOR inhibition with Rapamycin, after treatment with the c-MYC inhibitor or LY294002, the expression of the miRNA133a was diminished (Table 3). Thus, c-MYC is involved in pathways stimulating proliferation and also enhances the glycolytic phenotype of lymphoma cells. Inhibition of c-MYC therefore is an attractive strategy to inhibit both the altered glucose metabolism and proliferation in lymphoma cells. Further experiments are needed to characterize the exact molecular relationship between glycolytic inhibition and cell death and its mechanisms.

\section{Effect of inhibitors of MAPK pathways}

The p38-MAPK signaling pathway is involved in many cellular functions like differentiation, proliferation and induction of cell death. The exact role of p38-MAPK in a cancer cell depends on the cell type and the tumor stage [57]. In NHL, upregulation was shown in DLBCL [58] and an increased level of phosphorylated p38-MAPK has been correlated with malignancy and failure of response to CHOP treatment $[59,60]$. In our experiments, we did not find an influence of p38-MAPK inhibition on cell survival and proliferation, FDG uptake and expression of glycolysis-related genes and miRNAs. These results fit those published by Vega et al. [61] who reported on the lack of apoptosis-inducing effects of SB203580 in NHL cells. Furthermore, Elenitoba-Johnson et al. [58] reported that SB203580 had no effect on proliferation in one of three NHL cell lines, while p38-MAPK inhibition was effective in the other two indicating that the effect of a p38-MAPK inhibition is dependent on presently unknown cell line characteristics.

The MEK pathways are activated mainly in response to the stimulation of tyrosine kinase receptors [62]. MEK pathways are shown to be involved in an enhanced glucose uptake and the metabolic shift in cancer types with an activated BRAF-MAPK pathway by BRAF mutations like those found in melanoma [63]. Furthermore, MAPK pathways were shown to interact with enhanced glutamine metabolism in melanoma cells: In BRAFmutated melanoma cells that were MAPK inhibitorresistant, a greater uptake of glutamine and an increased sensitivity to glutamine was demonstrated compared to MAPK inhibitor-sensitive cells [64]. In addition, inhibitors of glutaminase were more efficient in MAPK-inhibitor-resistant cells with regard to decreased cell survival indicating that besides glucose metabolism, glutamine metabolism may be a suitable therapeutic target in cancer cells [64]. In lymphoma, no mutational activation of members of the MAPK pathways are described except in pediatric-type nodal follicular lymphoma, a variant of follicular lymphoma with invariably benign behavior, with a mutation frequency in the $M E K 1$ gene of $43 \%$ [65]. The data presented here show no influence of the MEK inhibitor PD98059 on the number of viable cells, glucose uptake and the expression of glycolysis-related genes and thus fit these literature data. Interestingly, we found an upregulation of the tumor suppressor miRNAs133a, -133b and -138-1 after PD98059 treatment indicating the involvement of MAPK in presently unknown oncogenic pathways.

\section{Effect of the glucose analog 2-DG}

The glucose analog 2-DG is an inhibitor of HK that is used to block the Warburg effect in cancer cells [66]. 2-DG is taken up into the cells via GLUTs and phosphorylated by $\mathrm{HK}$ to 2-deoxyglucose-6-phosphate which cannot be further metabolized and thus accumulates in the cell and interferes with the glycolytic pathway by inhibiting HK and phosphoglucose isomerase [66, 67].

Due to its ability to inhibit glycolysis, 2-DG has been evaluated as an anticancer agent in several cell systems [Review: 68]. In our lymphoma cell lines we found a decrease in cell viability after incubation with 2-DG for $48 \mathrm{~h}$ with IC50 values in the range of $2.86 \mathrm{mM}$ to $4.65 \mathrm{mM}$ with SU-DHL-6 being the most sensitive cell line (Fig. 4f; Table 1). The IC50 values found here are in the lower range of values reported in the literature for other cell systems (MCF7 breast cancer cells: $6.7 \mathrm{mM}$; LNCaP prostate cancer cells: $8.1 \mathrm{mM}$ [69]).

Although 2-DG decreases the number of viable cells in short-time cell culture experiments, it has not been effective as a single agent in vivo [68]. We therefore combined 2-DG with the inhibitors used in this study and investigated the effects of combined inhibition on cell viability (Table 2). Approx. half the concentrations used in the other experiments were used for combined treatment (Table 2). Synergistic effects were observed with the c-MYC-inhibitor 10058-F4, with LY294002 and with the p38 MAPK inhibitor SB203580 as well as with Rapamycin in 2 of 3 cell lines (Table 2).

A synergistic effect of a combined treatment with 2-DG and PI3K/mTOR inhibitors as found in our experiments has already been described by a few authors: In lung cancer cell lines, an analogue of Rapamycin hypersensitized cells to 2-DG treatment under hypoxic conditions [70]. Furthermore, a dual PI3K/mTOR inhibitor has recently been reported to have synergistic effect with 2-DG on cell survival in two cell lines of primary effusion lymphoma (PEL), a rare subtype of B-cell NHL [71]. A possible explanation for the synergistic action of inhibitors of the $\mathrm{PI} 3 \mathrm{~K} / \mathrm{mTOR}$ pathways with inhibitors of glycolysis was recently found in cells derived from various cancer types [72]. These authors reported on an escape from glycolysis addiction of tumor cells by an mTORC1-dependent 
circumvention of the 2-DG-mediated glycolysis block via the pentose phosphate pathway back to glycolysis [72].

Combined treatment with 2-DG and SB203580 has recently been described in pancreatic and ovarian cell lines [73] with similar synergistic effects on cell survival in five of six cell lines as described here. On the other hand, Cheng et al. reported that the p38-MAPK pathway is necessary for apoptosis induced by 2-DG in pancreatic cancer cells [74]. Taken together, these data suggest that the effect of p38-MAPK inhibitors depends on the individual cell context and on activation pattern of signaling pathways within the cell.

Up to now, to the best of our knowledge, no data on the efficacy of a combined treatment with 2-DG and the c-MYC inhibitor or MEK inhibitor like PD98059 are available. Inhibition of c-MYC alone resulted in significant decrease of viable cells which was synergistically enhanced by 2-DG in our cells (Table 3). On the other hand, combination of the MEK inhibitor PD98059 with 2-DG showed a better effect than treatment with 2-DG alone (Table 3). Although we do not know the molecular reasons at this time, combined treatment of NHL cells with 2-DG and inhibitors of the PI3K/AKT pathway, c-MYC and p38 MAPK intracellular signaling pathways may be a promising new therapeutic option. Further experiments will provide further insights into the molecular background of cell inhibition and the mechanism of cell death induced by these substances.

\section{Conclusions}

Taken together, our results suggest that PI3K/mTOR inhibitors as well as the c-MYC inhibitor decreased the viability of lymphoma cells, reduced glucose uptake and glucose metabolism, and downregulated the expression of glycolysis-associated genes and glucose metabolismregulating miRNAs. Our results that 2-DG decreased viability of all cell lines support the hypothesis that lymphoma cells are highly dependent upon high glycolysis for survival. In combination with inhibitors of intracellular signaling pathways, 2-DG treatment may be an option to reduce proliferation of NHL cells.

\footnotetext{
Abbreviations

2-DG: 2-deoxy-D-glucose; ABC: activated B cell like; AKT: protein kinase B; AML: acute myeloid leukemia; DLBCL: diffuse large B cell lymphoma; FBS: fetal bovine serum; FDG: ${ }^{18}$ F-fluoro-2-deoxy-D-glucose; G6Pase: glucose-6-phosphatase; GCB: germinal center B cell like; GLUTS: glucose transporters; HIF-1: hypoxia-inducible factor 1 ; HK: hexokinase; HPRT1: hypoxanthine phosphoribosyltransferase 1; LDHA: lactate dehydrogenase A; MAPK: mitogen-activated protein kinase; MEK: mitogen-activated protein kinase kinase; miRNAs: microRNAs; mTOR: mammalian target of rapamycin; NHL: non-Hodgkin's lymphoma; PET: positron emission tomography; PI3K: phosphoinositide 3-kinase; PTEN: phosphatase and tensin homolog.
}

\section{Authors' contributions}

MBP drafted the project design, planned and conducted experiments, analyzed the data and wrote the text. NBB conducted experiments and analysed data. $A B$ contributed to project design and discussion. UD participated in project design, writing and discussion. SM contributed to project design, FDG uptake assay, text writing and discussion of the data and text. All authors read and approved the final manuscript.

\section{Author details \\ ${ }^{1}$ Department of Nuclear Medicine, University Hospital Essen, Hufelandstr. 55, 45122 Essen, Germany. ${ }^{2}$ Department of Hematology, University Hospital Essen, Hufelandstr. 55, 45122 Essen, Germany. ${ }^{3}$ Present Address: Department of Clinical Chemistry, University Hospital Essen, Hufelandstr. 55, 45122 Essen, Germany. ${ }^{4}$ Present Address: Institute of Pathology, University Hospital Essen, Hufelandstr. 55, 45122 Essen, Germany.}

\section{Acknowledgements \\ None.}

Competing interests

The authors declare that they have no competing interests.

\section{Availability of data and materials}

The datasets used and/or analyzed during the current study are available from the corresponding author on reasonable request.

\section{Consent for publication}

Not applicable.

Ethics approval and consent to participate

Not applicable.

\section{Funding}

The study was supported by the Dr. Werner Jackstädt-Stiftung (Wuppertal, Germany; Grant to SPM).

\section{Publisher's Note}

Springer Nature remains neutral with regard to jurisdictional claims in published maps and institutional affiliations.

Received: 3 May 2017 Accepted: 4 July 2017

Published online: 19 July 2017

\section{References}

1. Kroemer G, Pouyssegur J. Tumor cell metabolism: cancer's achilles' heel. Cancer Cell. 2008;13:472-82.

2. Hsu PP, Sabatini DM. Cancer cell metabolism: warburg and beyond. Cell. 2008;134:703-7.

3. Levine AJ, Puzio-Kuter AM. The control of the metabolic switch in cancers by oncogenes and tumor suppressor genes. Science. 2010;330:1340-4.

4. Lu J, Tan M, Cai Q. The Warburg effect in tumor progression: mitochondrial oxidative metabolism as an anti-tumor mechanism. Cancer Lett. 2015;356:156-64.

5. Warburg O. On the origin of cancer cells. Science. 1956;123:309-14.

6. Heron DE, Andrade RS, Beriwal S, Smith RP. PET-CT in radiation oncology: the impact on diagnosis, treatment planning, and assessment of treatment response. Am J Clin Oncol. 2008;31:352-62.

7. Rigo P, Paulus P, Kaschten BJ, Hustinx R, Bury T, Jerusalem G, Benoit T, Foidart WJ. Oncological application of positron emission tomography with fluorine-18 fluorodeoxyglucose. Eur J Nucl Med. 1996;23:1641-74.

8. Kelloff GJ, Hoffman JM, Johnson B, Scher HI, Siegel BA, Cheng EY, Cheson BD, O'Shaughnessy J, Guyton KZ, Mankoff DA, Shankar L, Larson SM, Sigman CC, Schilsky RL, Sullivan DC. Progress and promise of FDG-PET imaging for cancer patient management and oncologic drug development. Clin Cancer Res. 2005;11:2785-808. 
9. Cairns RA, Harris IS, MakTW. Regulation of cancer metabolism. Nat Rev Cancer. 2011;11:85-95.

10. Szablewski L. Expression of glucose transporters in cancers. Biochim Biophys Acta. 2013;1835:164-9.

11. Bartel DP. MicroRNAs: target recognition and regulatory functions. Cell. 2009;136:215-33.

12. Hatziapostolou M, Polytarchou C, lliopoulos D. miRNAs link metabolic reprogramming to oncogenesis. Trends Endocrinol Metabol. 2013;24:361-73.

13. Chen $B$, Li H, Zeng X, Yang P, Liu X, Zhao X, Liang S. Roles of microRNA on cancer cell metabolism. J Transl Med. 2012;10:228.

14. Gee HE, Ivan C, Calin GA, Ivan M. HypoxamiTs and cancer: from biology to targeted therapy. Antioxid Redox Signal. 2014;21:1220-38.

15. Armitage JO, Weisenburger DD. New approaches to classifying nonHodgkin's lymphoma: clinical features of the major histologic subtypes. Non-Hodgkin's lymphoma classification project. J Clin Oncol. 1998;16:2780-95.

16. Schöder H, Noy A, Gönen M, Weng L, Green D, Erdi YE, Larson SM, Yeung HW. Intensity of 18 fluorodeoxyglucose uptake in positron emission tomography distinguishes between indolent and aggressive non-Hodgkin's lymphoma. J Clin Oncol. 2005;23:4643-51.

17. Chihara D, Oki Y, Onoda H, Taji H, Yamamoto K, Tamaki T, Morishima Y. High maximum standard uptake value (SUVmax) on PET scan is associated with shorter survival in patients with diffuse large B cell lymphoma. Int J Hematol. 2011;93:502-8.

18. Maxwell SA, Mousavi-Fard S. Non-Hodgkin's B-cell lymphoma: advances in molecular strategies targeting drug resistance. Exp Biol Med (Maywood). 2013;238:971-90.

19. Barrington SF, Mikhaeel NG, Kostakoglu L, Meignan M, Hutchings M, Mueller SP, Schwartz LH, Zucca E, Fisher RI, Trotman J, Hoekstra OS, Hicks RJ, O'Doherty MJ, Hustinx R, Biggi A, Cheson BD. Role of imaging in the staging and response assessment of lymphoma: consensus of the International Conference on Malignant Lymphomas Imaging Working Group. J Clin Oncol. 2014;32:3048-58.

20. Cheson BD, Fisher RI, Barrington SF, Cavalli F, Schwartz LH, Zucca E, Lister TA, Alliance, Australasian Leukaemia and Lymphoma Group. Eastern Cooperative Oncology Group; European Mantle Cell Lymphoma Consortium; Italian Lymphoma Foundation; European Organisation for Research; Treatment of Cancer/Dutch Hemato-Oncology Group; Grupo Español de Médula Ósea; German High-Grade Lymphoma Study Group; German Hodgkin's Study Group; Japanese Lymphorra Study Group; Lymphoma Study Association; NCIC Clinical Trials Group; Nordic Lymphoma Study Group; Southwest Oncology Group; United Kingdom National Cancer Research Institute. Recommendations for initial evaluation, staging, and response assessment of Hodgkin and non-Hodgkin lymphoma: the Lugano classification. J Clin Oncol. 2014;32:3059-68.

21. Duehrsen U, Hüttmann A, Müller S, Hertenstein B, Kotzerke J, Mesters R, Franzius C, Kroschinsky F, Weckesser M, Franzke A, Bengel F, Dürig J, Matschke J, Pöppel T, Rekowski J, Ose C, Brinkmann M, LaRosée P, Freesmeyer M, Hertel A, Hoeffkes H-G, Behringer D, Prange-Krex G, Wilop S, Krohn T, Fricke E, Griesshammer M, Giagounidis A, Raghavachar A, Maschmeyer G, Brink I, Brecht A, Haberkorn U, Gaska T, Klapper W, Hoelzer D, Jöckel K-H, Scherag A, Bockisch A. Positron Emission Tomography (PET) guided therapy of aggressive lymphomas - a randomized controlled trial comparing different treatment approaches based on interim PET results (PETAL Trial). Blood. 2014;124:391.

22. Luminari S, Ceriani L, Dührsen U. FDG-PET(CT)-adapted trials in nonHodgkin lymphoma. Clin Transl Imaging. 2015;3:295-307.

23. Yin X, Giap C, Lazo JS, Prochownik EV. Low molecular weight inhibitors of Myc-Max interaction and function. Oncogene. 2003;22:6151-9.

24. Lenz G, Nagel I, Siebert R, Roschke AV, Sanger W, Wright GW, Dave SS, Tan B, Zhao H, Rosenwald A, Muller-Hermelink HK, Gascoyne RD, Campo E, Jaffe ES, Smeland EB, Fisher RI, KuehI WM, Chan WC, Staudt LM. Aberrant immunoglobulin class switch recombination and switch translocations in activated B cell-like diffuse large B cell lymphoma. J Exp Med. 2007:204:633-43.

25. Yamada K, Brink I, Bissé E, Epting T, Engelhardt R. Factors influencing [F-18] 2-fluoro-2-deoxy-D-glucose (F-18 FDG) uptake in melanoma cells: the role of proliferation rate, viability, glucose transporter expression and hexokinase activity. J Dermatol. 2005;32:316-34.
26. Livak KJ, Schmittgen TD. Analysis of relative gene expression data using realtime quantitative PCR and the $2^{-\Delta \Delta C T}$ method. Methods. 2001;25:402-8.

27. Drewinko B, Loo TL, Brown JA, Gottlieb JA, Freireich EJ. Combination chemotherapy in vitro with adriamycin. Observations of additive, antagonistic and synergistic effects when used in two-drug combination on cultured human lymphoma cells. Cancer Biochem Biophys. 1976;1:187-95.

28. Davoren PA, McNeill RE, Lowery AJ, Kerin MJ, Miller N. Identification of suitable endogenous control genes for microRNA gene expression analysis in human breast cancer. BMC Mol Biol. 2008:9:76.

29. Andreasen D, Fog JU, Biggs W, Salomon J, Dahslveen IK, Baker A, Mouritzen P. Improved microRNA quantification in total RNA from clinical samples. Methods. 2010;50:56-9.

30. Yuan JS, Reed A, Chen F, Stewart CN Jr. Statistical analysis of real-time PCR data. BMC Bioinform. 2006;7:85

31. Hanahan D, Weinberg RA. Hallmarks of cancer: the next generation. Cell. 2011;144:646-74.

32. Yu $\mathrm{L}$, Chen $\mathrm{X}$, Wang $\mathrm{L}$, Chen $\mathrm{S}$. The sweet trap in tumors: aerobic glycolysis and potential targets for therapy. Oncotarget. 2016;7:38908-26.

33. Wong KK, Engelman JA, Cantley LC. Targeting the PI3K signaling pathway in cancer. Curr Opin Genet Dev. 2010;20:87-90.

34. Westin JR. Status of PI3K/Akt/mTOR pathway inhibitors in lymphoma. Clin Lymph Myeloma Leuk. 2014;14:335-42.

35. Blachly JS, Baiocchi RA. Targeting PI3-kinase (PI3K), AKT and mTOR axis in lymphoma. Br J Haematol. 2014;167:19-32.

36. Fan Y, Dickman KG, Zong WX. Akt and c-Myc differentially activate cellular metabolic programs and prime cells to bioenergetics inhibition. J Biol Chem. 2010;285:7324-33.

37. Robey RB, Hay N. Is Akt the "Warburg kinase"? Akt energy metabolism interactions and oncogenesis. Sem Cancer Biol. 2009;19:25-31.

38. Inoki K, Corraadetti MN, Guan KL. Dysregulation of the TSC-mTOR pathway in human disease. Nat Genet. 2005;37:19-24.

39. Ezell SA, Wang S, Bihani T, Lai Z, Grosskurth SE, Tepsuporn S, Davies BR, Huszar $D$, Byth DK. Differential regulation of mTOR signaling determines sensitivity of AKT inhibition in diffuse B cell lymphoma. Oncotarget. 2016;7:9163-74.

40. Smith SM, van Besien K, Karrison T, Dancey J, McLaughlin P, Younes A, Smith S, Stiff P, Lester E, Modi S, Doyle LA, Vokes EE, Pro B. Temsirolimus has activity in non-mantle cell non-Hodgkin's lymphoma subtypes: the University of Chicago phase II consortium. J Clin Oncol. 2010;28:4740-6.

41. Witzig TE, Reeder CB, Laplant BR, Gupta M, Johnston PB, Micallef IN, Porrata LF, Ansell SM, Colgan JP, Jacobsen ED, Ghobrial IM, Habermann TM. A phase II trial of the oral mTOR inhibitor everolimus in relapsed aggressive lymphoma. Leukemia. 2011;25:341-7.

42. Rashmi R, DeSelm C, Helms C, Bowcock A, Rogers BE, Rader J, Grigsby PW, Schwarz JK. AKT inhibitors promote cell death in cervical cancer through disruption of mTOR signaling and glucose uptake. PLOS ONE. 2014;9:e92948.

43. Makinoshima H, Takita M, Saruwatari K, Umemura S, Obata Y, Ishii G, Matsumoto S, Sugiyama E, Ochiai A, Abe R, Goto K, Esumi H, Tsuchihara K. Signaling through the phosphatidylinositol 3-kinase (PI3K)/mammalian target of rapamycin (mTOR) axis is responsible for aerobic glycolysis mediated by glucose transporter in epidermal growth factor receptor (EGFR)-mutated lung adenocarcinoma. J Biol Chem. 2015;290:17495-504.

44. Kittipongdaja W, Wu X, Garner J, Liu X, Komas SM, Hwang ST, Schieke SM. Rapamycin suppresses tumor growth and alters the metabolic phenotype in T-cell lymphoma. J Invest Dermatol. 2015;135:2301-8.

45. LoPiccolo J, Blumenthal GM, Bernstein WB, Dennis PA. Targeting the PI3K/ Akt/mTOR pathway: effective combinations and clinical considerations. Drug Resist Update. 2008;11:32-50.

46. Dang CV. MYC on the path to cancer. Cell. 2012;149:22-35.

47. Ott G, Rosenwald A, Campo E. Understanding MYC driven aggressive B-cell lymphomas: pathogenesis and classification. Blood. 2013;122:3884-91.

48. Leucci E, Cocco M, Onnis A, De Falco G, van Cleef P, Bellan C, van Rijk A, Nyagol J, Byakika B, Lazzi S, Tosi P, van Krieken H, Leoncini L. MYCtranslocation-negative classical Burkitt lymphoma cases: an alternative pathogenetic mechanism involving miRNA deregulation. J Pathol. 2008;216:440-50.

49. Ruzinova MB, Caron T, Rodig SJ. Altered subcellular localization of C-Myc protein identifies aggressive B-cell lymphomas harboring a c-MYC translocation. Am J Surg Pathol. 2010;34:882-91. 
50. Shajahan-Haq AN, Cook KL, Schwartz-Roberts JL, Eltayeb AE, Demas DM, Warri AM, Facey COB, Hilakivi-Clarke LA, Clarke R. MYC regulates the unfolded protein response and glucose and glutamin uptake in endocrine resistant breast cancer. Mol Cancer. 2014;13:239.

51. Holien T, Misund K, Elsen OE, Baranowska KA, Buene G, Borset M, Waage A, Sundan A. MYC amplifications in myeloma cell lines: correlation with MYC-inhibitor efficacy. Oncotarget. 2015;6:22698-705.

52. Wang J, Ma X, Jones HM, Chan LL-Y, Song F, Zhang W, Bae-Jump VL, Zhou C. Evaluation of the antitumor effects of c-Myc-Max heterodimerization inhibitor 100258-F4 in ovarian cancer cells. J Translat Med. 2014;12:226.

53. Lin C-P, Liu J-D, Chow J-M, Liu C-R, Liu HE. Small-molecule c-Myc inhibitor, 10058-F4, inhibits proliferation, downregulates human telomerase reverse transcriptase and enhances chemosensitivity in human hepatocellular carcinoma cells. Anti Cancer Drugs. 2007;18:161-70.

54. Huang M-J, Cheng Y-C, Liu C-R, Lin S, Liu HE. A small-molecule C-Myc inhibitor, 10058-F4, induces cell-cycle arrest, apoptosis, and myeloid differentiation of human acute myeloid leukemia. Exp Hematol. 2006:34:1480-9.

55. Shim H, Dolde C, Lewis BC, Wu CS, Dang G, Jungmann RA, Dalla-Favera R, Dang CV. c-Myc transactivation of LDH-A: implications for tumor metabolism and growth. Proc Natl Acad Sci USA. 1997;94:6658-63.

56. Osthus RC, Shim H, Kim S, Li Q, Reddy R, Mukherjee M, Xu Y, Wonsey D, Lee LY, Dang CV. Deregulation of glucose transporter 1 and glycolytic gene expression by c-Myc. J Biol Chem. 2000;275:21797-800.

57. Cuadrado A, Nebreda AR. Mechanisms and functions of p38 MAPK signaling. Biochem J. 2010;429:403-17.

58. Elenitoba-Johnson KS, Jenson SD, Abbott RT, Palais RA, Bohling SD, Lin Z, Tripp S, Shami PJ, Wang LY, Coupland RW, Buclstein R, Perez-Ordonz B, Perkins SL, Dube ID, Lim MS. Involvement of multiple signaling pathways in follicular lymphoma transformation: p38-mitogen-activated protein kinase as a target for therapy. Proc Natl Acad Sci USA. 2003;100:7259-64

59. Vega GG, Avilés-Salas A, Chalapud JR, Martinez-Paniagua M, Pelayo R, Mayani H, Hernandez-Pando R, Martinez-Maza O, Huerta-Yepez S, Bonavida B, Vega MI. p38 MAPK expression and activation predicts failure of response to $\mathrm{CHOP}$ in patients with diffuse large B-cell lymphoma. BMC Cancer. 2015;15:722.

60. Wagner EF, Nebreda AR. Signal integration by JNK and p38 MAPK pathways in cancer development. Nat Rev Cancer. 2009;9:537-49.

61. Vega MI, Huerta-Yepaz S, Garban H, Jazirehi A, Emmanouilides C, Bonavida B. Rituximab inhibits p38 MAPK activity in 2F7 B NHL and decreases IL-10 transcription: pivotal role of p38 MAPK in drug resistance. Oncogene. 2004;23:3530-40.

62. Pearson G, Robinson F, Beers Gibson T, Xu BE, Karandikar M, Berman K, Cobb MH. Mitogen-activated protein (MAP) kinase pathways: regulation and physiological functions. Endocr Rev. 2001;22:153-83.
63. Miniotis MF, Arunan V, Eykyn TR, Marais R, Workman P, Leach MO, Beloueche-Babari M. MEK1/2 inhibition decreases lactate in BRAF-driven human cancer cells. Cancer Res. 2013;73:4039-49.

64. Hernandez-Davies JE, Tran TQ, Reid MA, Rosales KR, Lowman XH, Pan M, Moriceau G, Yang Y, Wu J, Lo RS, Kong M. Vemurafenib resistance reprograms melanoma cells towards glutamine dependence. J Transl Med. 2015;13:210.

65. Louissaint A Jr, Schafernak KT, Geyer J, Kovach AE, Ghandi M, Gratzinger D, Roth CG, Paxton CN, Kim S, Namgyal C, Morgan EA, Neuberg DS, South ST, Harris MH, Hasserjian RP, Hochberg EP, Garraway LA, Harris NL, Weinstock DM. Pediatric-type nodal follicular lymphoma: a biologically distinct lymphoma with frequent MAP kinase pathway mutations. Blood. 2016;128:1093-100

66. Pelicano H, Martin DS, Xu RH, Huang P. Glycolysis inhibition for anticancer treatment. Oncogene. 2006;25:4633-46.

67. Chen W, Gueron M. The inhibition of bovine heart hexokinase by 2-deoxy-D-glucose-6-phosphate: characterization by 31PP NMR and metabolic implications. Biochimie. 1992;74:867-73.

68. Kuntz S, Mazerbourg S, Boisbrun M, Cerella C, Diederich M, Grillier-Vuissoz I, Flament $\mathrm{S}$. Energy restriction mimetic agents to target cancer cells: comparison between 2-deoxyglucose and thiazolidinediones. Biochem Pharmacol. 2014;92:102-11.

69. Tagg SL, Foster PA, Leese MP, Potter BV, Reed MJ, Purohit A, Newman SP. 2-Methoxyoestradiol-3,17-O, O-bis sulphamate and 2-deoxy-D-glucose in combination: a potential treatment for breast and prostate cancer. $\mathrm{Br}$ J Cancer. 2008;99:1842-8

70. Wangpaichitr M, Savaraj N, Maher J, Kurtoglu M, Lampidis TJ. Intrinsically lower AKT, mammalian target of rapamycin, and hypoxia-inducible factor activity correlates with increased sensitivity to 2-deoxy-D-glucose under hypoxia in lung cancer cell lines. Mol Cancer Ther. 2008;7:1506-13.

71. Mediani L, Gibellini F, Bertacchini J, Frasson C, Bosco R, Accordi B, Basso G, Bonora M, Calabrò ML, Mattiolo A, Sgarbi G, Baracca A, Pinton P, Riva G, Rampazzo E, Petrizza L, Prodi L, Milani D, Luppi M, Potenza L, De Pol A, Cocco L, Capitani S, Marmiroli S. Reversal of the glycolytic phenotype of primary effusion lymphoma cells by combined targeting of cellular metabolism and PI3K/Akt/mTOR signaling. Oncotarget. 2015;7:5521-37.

72. Pusapati RV, Daimen A, Wilson C, Sandova W, Gao M, Haley B, Baudy AR, Hatzivassiliou G, Evangelista M, Settleman J. mTORC1-dependent metabolic reprogramming underlies escape from glycolysis addiction in cancer cells. Cancer Cell. 2016;29:548-62.

73. Malm SW, Hanke NT, Gill A, Carbajal L, Baker AF. The anti-tumor efficacy of 2-deoxyglucose and D-allose are enhanced with p38 inhibition in pancreatic and ovarian cell lines. J Exp Clin Cancer Res. 2015;34:31.

74. Cheng Y, Diao D-M, Zhang H, Song Y-C, Dang C-X. Proliferation enhanced by NGF-NTRK I signaling makes pancreatic cancer cells more sensitive to 2DG induced apoptosis. Int J Med Sci. 2013;10:634-40.

\section{Submit your next manuscript to BioMed Central and we will help you at every step:}

- We accept pre-submission inquiries

- Our selector tool helps you to find the most relevant journal

- We provide round the clock customer support

- Convenient online submission

- Thorough peer review

- Inclusion in PubMed and all major indexing services

- Maximum visibility for your research

Submit your manuscript at www.biomedcentral.com/submit 